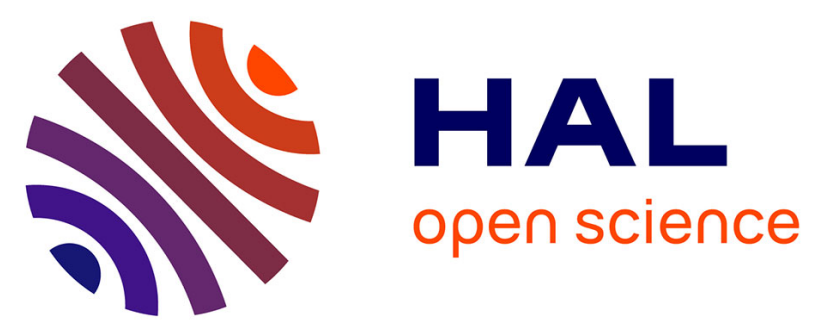

\title{
Protection of reinforcement steel corrosion by phenyl phosphonic acid pre-treatment PART I: Tests in solutions simulating the electrolyte in the pores of fresh concrete
}

\author{
Naceur Etteyeb, L Dhouibi, Hisasi Takenouti, E Triki
}

\section{To cite this version:}

Naceur Etteyeb, L Dhouibi, Hisasi Takenouti, E Triki. Protection of reinforcement steel corrosion by phenyl phosphonic acid pre-treatment PART I: Tests in solutions simulating the electrolyte in the pores of fresh concrete. Cement and Concrete Composites, 2015, 55, pp.241 - 249. 10.1016/j.cemconcomp.2014.07.025 . hal-01095148

\author{
HAL Id: hal-01095148 \\ https://hal.science/hal-01095148
}

Submitted on 15 Dec 2014

HAL is a multi-disciplinary open access archive for the deposit and dissemination of scientific research documents, whether they are published or not. The documents may come from teaching and research institutions in France or abroad, or from public or private research centers.
L'archive ouverte pluridisciplinaire HAL, est destinée au dépôt et à la diffusion de documents scientifiques de niveau recherche, publiés ou non, émanant des établissements d'enseignement et de recherche français ou étrangers, des laboratoires publics ou privés. 


\title{
Protection of reinforcement steel corrosion by phenyl phosphonic acid pre-treatment
}

\section{PART I: Tests in solutions simulating the electrolyte in the pores of fresh concrete}

\author{
N. Etteyeb ${ }^{1,2 *}$ L. Dhouibi ${ }^{2}$, H. Takenouti ${ }^{3,4}$, E. Triki ${ }^{2}$ \\ ${ }^{1}$.Institut Supérieur de Biologie Appliquée de Médenine, Université de Gabes, \\ km 22,5; Route el Jorf, 4111 Médenine, Tunisie \\ 2. Laboratoire de Mécanique Appliquée et Ingénierie, Equipe «COPROMET », Ecole Nationale \\ d’ingénieurs de Tunis, Univ. Tunis El Manar, BP37, Le Belvédère 1002, Tunis, Tunisia. \\ ${ }^{3}$ CNRS, UMR 8235, Laboratoire Interfaces et Systèmes Electrochimiques (LISE), \\ Case 133, 4 Place Jussieu, 75252 Paris Cedex 05, France. \\ ${ }^{4}$ Sorbonne Universités, UMR 8235, LISE, Case 133, 4 Place Jussieu, 75252 Paris Cedex 05, France.
}

\begin{abstract}
The carbon steel electrodes were first treated by immersion in $0.1 \mathrm{M}$ phenyl phosphonic acid $\left(\mathrm{C}_{6} \mathrm{H}_{5} \mathrm{P}(\mathrm{O})(\mathrm{OH})_{2}\right.$, PPA) solution during 24 or 72 hours, then they were transferred into the corrosion test solution representing interstice pore electrolyte polluted by seawater: sat. $\left.\mathrm{Ca}(\mathrm{OH})_{2}+0.5 \mathrm{M} \mathrm{NaCl}\right)$ to evaluate the protective effectiveness of the pre-treatment. The investigation was performed essentially by polarization curves and electrochemical impedance measurements with rotating disc electrode. Very high protective effect was observed with steel pre-treated during 72 hours with stationary electrode. From polarization and electrochemical impedance spectroscopy experiments, the protective efficiency was found to be in the $90-99 \%$ range for 72 hour pre-treatment. This protective property remains effective even one month immersion. EDS analysis showed the presence of the phosphorus on the steel surface, probably due to the presence of iron-PPA complex.
\end{abstract}

Keywords: Pre-treatment, Electrochemical impedance spectroscopy, Phenyl phosphonic Acid, Protective efficiency 
* Corresponding author. naceur.etteyeb@gmail.com;

Phone: +216-97-208-278; Fax: +216-75-633-918.

\section{INTRODUCTION}

Concrete usually provides an excellent corrosion protection for reinforcing steel because its high alkaline environment results in the formation of a tightly adhering passive film, which protects steel from corrosion. However, chloride ions are considered as the major cause to shorten the lifetime steel reinforcement by corrosion together with the carbonation process. To minimize the corrosion processes, various procedures are proposed. Among them, the use of corrosion inhibitors was considered as a possible and cost effective solution [1-7].

Two approaches are generally used to evaluate the efficiency of inhibitors for concrete application; one uses simulated pore solution testing [8], and the other uses actual concrete or mortar specimens [9-11]. Both methods are sometimes used in conjunction [12]. Electrochemical techniques are actually used in both approaches.

Simulated pore solutions usually employ a saturated calcium hydroxide solution [12-14] with or without chloride addition. This methodology allows evaluating rapidly the inhibitor efficiency and determining the simplified system the inhibition mechanisms. However, further tests in mortar and concrete are needed because the possible interaction of the inhibitor with the solid phases of the cement paste would modify the concrete properties.

The molecules used to mitigate the corrosion of reinforcement steel contain generally phosphorus. They may be distinguished two groups; inorganic and organic.

Inorganic inhibitors, such as sodium phosphate $\left(\mathrm{Na}_{3} \mathrm{PO}_{4}\right)$ and sodium monofluorophosphate $\left(\mathrm{Na}_{2} \mathrm{PO}_{3} \mathrm{~F}\right)$ were tested as corrosion inhibitors for steel reinforcement for concrete structure [15-20]. Those previous works have demonstrated that sodium phosphate inhibits pitting corrosion of steel in pore solution if its concentration is equal or higher than the chloride concentration [15]. However, its efficiency is partially lost in concrete. Sodium 
monofluorophosphate also prevents or decreases the rate of reinforcement corrosion in the presence of chloride [18], and in the presence of carbonation [19, 20], but its efficiency depends on the method of application to concrete.

Organic inhibitors such as nitrilotris(methylenephosphonic acid) was also tried as inhibitor and found to inhibit the cathodic reaction in a saturated $\mathrm{Ca}(\mathrm{OH})_{2}$ solution [21]. Hydroxyethylidene-diphosphonic acid was also considered as corrosion inhibitor with nontoxicity in cooling water [22-25]. Phosphonic acids prevent the scale formation and corrosion process because of hydrolytic stability, ability to form complexes with iron [26-28].

Rajendran et al. [27] have concluded that, in solution, both the phosphonate group and the phenyl group of the phenyl phosphonic acid (PPA) are involved in the formation of a complex with $\mathrm{Zn}^{2+}$ and $\mathrm{Fe}^{2+}$ on the one hand. On the other hand, in the solid state, only the phosphonate group of PPA is involved in the formation of a complex with $\mathrm{Zn}^{2+}$ and $\mathrm{Fe}^{2+}$. To et al. [29] have tested three phosphonate compounds as corrosion inhibitors of carbon steel in chloride media. The investigation has demonstrated that Ethyllaurylphosphonate (ELP) formed a protective film. This film was relatively thick, porous, and was identified as the Fe(ELP) $)_{2}$ complex.

It is also important to recall that the phosphate-based inhibitors are generally efficient for iron in alkaline medium, however these substances may combine with $\mathrm{Ca}^{2+}$ of the concrete before reacting with steel, and its protective effect is strongly jeopardized. This is the reason that these substances may be used as pre-treatment of reinforcement steel before embedding into the concrete. Our previous investigation [30] showed that the pre-treatment of steel rebars hinders the initiation of corrosion. The immersion of reinforcement rods during 7 days in $0.5 \mathrm{M} \mathrm{Na}_{3} \mathrm{PO}_{4}$ favours the formation of a passive layer on the steel surface, which is able to resist for longer period to the aggression of chlorides. Another study [16] demonstrated that the preventive method (pre-treatment) seems to be the better choice, since it leads to higher 
impedance values and consequently to lower corrosion rates. The impregnation duration of steel in $0.5 \mathrm{M} \mathrm{Na}_{3} \mathrm{PO}_{4}$ solution and the electrode rotation speed considerably influence the phosphate-based film resistance against corrosion.

The present paper deals with the protective effect of phenyl phosphonic acid $\left(\mathrm{C}_{6} \mathrm{H}_{5} \mathrm{P}(\mathrm{O})(\mathrm{OH})_{2}\right.$, PPA) used as pre-treatment solution against the corrosion reinforcement steel in a solution simulating interstitial electrolyte of concrete contaminated by seawater. The study was essentially performed by means of electrochemical techniques.

\section{EXPERIMENTAL CONDITIONS}

\subsection{ELECTRODES AND ELECTROLYSING CELL}

A classic electrochemical cell with three-electrode configuration was used in this study: a platinum grid, a rotating disk of steel, and a saturated calomel electrode respectively as counter, working, and reference electrodes.

The working electrode was made of cylinder rod of carbon steel $(\mathrm{C} \approx 0.22 \%)$ of $5 \mathrm{~mm}$ diameter. The lateral part was covered with a cataphoretic epoxy-amine base paint (PPG; WT724 + P962). First, the paint was electro-deposited cathodically at dc voltage of $180 \mathrm{~V}$ during $4 \mathrm{~min}$, and then cured at $180{ }^{\circ} \mathrm{C}$ for $30 \mathrm{~min}$. After that, the electrode was embedded into an epoxy resin (Buhler; Epoxycure), and worked out to a cylinder shape, the outer diameter of which was $21 \mathrm{~mm}$. The cataphoretic coating allowed avoiding any infiltration of electrolyte between the metal and epoxy resin interface. Only the cross-section of the steel rod embedded in the epoxy resin was used to form a rotating-disk electrode. Just before each experiment, the electrode surface was abraded by emery-paper up to 1200 grade.

\subsection{CORROSION TEST SOLUTIONS}

The corrosion test solution was prepared with de-ionized water and reagent grade chemicals: saturated $\mathrm{Ca}(\mathrm{OH})_{2}+0.5 \mathrm{M} \mathrm{NaCl}$. This solution simulates the interstitial electrolyte of 
concrete contaminated by seawater [31-36]. The solution $\mathrm{pH}$ of the corrosion test solution was 13.

The pre-treatment solution was a $0.1 \mathrm{M}$ phenyl phosphonic acid (PPA). The $\mathrm{pH}$ of the phosphonic solution was 1.85 . The working electrode was pre-treated during 24 or 72 hours in 0.1 M PPA, and then transferred quickly to the corrosion test solution. The solution was not stirred and all electrochemical tests were performed at room temperature without purging the dissolved oxygen, but the electrochemical cell was closed tightly to minimize carbonation of the solution.

\subsection{ELECTROCHEMICAL TECHNIQUES}

\subsubsection{Polarisation measurements}

The potentiodynamic polarisation curves were recorded using the Gamry instrument (PC4/300C). Each experiment was carried out with a freshly abraded electrode. Prior to the measurements, the electrode was left at the open-circuit conditions during 2 hours for sufficient potential stabilization. The potential sweep-rate was $10 \mathrm{mV} \mathrm{s}^{-1}$, and the disk rotation speed was 0,500 , or $1000 \mathrm{rpm}$. The potential sweep began from the potential slightly more anodic $\left(\mathrm{ca} .20 \mathrm{mV}\right.$ ) from the open circuit one $\left(E_{\mathrm{OC}}\right)$ for the cathodic polarization curves. Conversely, anodic polarization curves were stated from ca. $20 \mathrm{mV}$ more negative potential than $E_{\mathrm{OC}}$.

\subsubsection{Impedance measurements}

Impedance (EIS) measurements were performed by using the Gamry equipment (PC4/300C). The measuring frequency ranged from $100 \mathrm{kHz}$ to $10 \mathrm{mHz}$ with 5 points per decade using a $10 \mathrm{mV}$ (rms) sinusoidal potential perturbation. Experiments were performed in the potentiostatic mode at $E_{\mathrm{OC}}$. 
Before any impedance measurements, unless otherwise indicated, the electrode was held at the open circuit conditions during 2 hours for the stabilization of the system with stationary electrode, that is, the disk rotation speed at $\Omega=0$.

\subsubsection{Electrochemical quartz crystal microbalance (EQCM)}

For electrochemical quartz crystal microbalance (EQCM) experiments, the iron was plated cathodically (electrodeposited iron) on a quartz crystal blade (6 MHz AT-cut) upon which a thin gold layer was vacuum deposited previously. The surface area of EQCM electrode was $0.22 \mathrm{~cm}^{2}$. The quartz crystal electrode was fixed with electrical conducting glue on an epoxy resin reinforced by glass-fiber with electrical circuitry. The iron deposited surface was set outside, and a silicon sealant (Sodiema, Aracolle) allowed avoiding the solution leakage to the quartz backside [37].

For the gravimetric measurements, the results are presented as the mass variation with respect to time. The mass changes were derived from the observed frequency changes using the Sauerbrey equation [38]:

$$
\Delta f=-K_{\mathrm{s}} \Delta m
$$

$\Delta f$ is the frequency change, $\Delta m$ is mass change and $K_{\mathrm{s}}$ is the constant depending upon the oscillation frequency of the quartz. $K_{\mathrm{s}}$ was experimentally determined previously by the

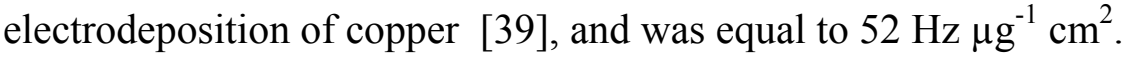

After each test, the surface morphology of the electrode was examined by a scanning electron microscope (SEM; Leica Stereoscan 440), and elemental analyses were performed with EDS (Princeton Gamma-Tech). 


\section{RESULTS AND DISCUSSION}

\subsection{PolariZATION CURVES}

Fig. 1 presents the anodic curves obtained for various rotation speeds for carbon steel without and with pre-treatment during 24 or $72 \mathrm{~h}$ in $0.1 \mathrm{M}$ PPA solution.

$<$ Fig. $1>$

For all cases, the polarisation curves exhibit a current plateau, clearly marked for the stationary electrode whereas just an inflexion point is revealed for the highest rotation speed. Beyond this plateau, a steep current increase was observed. The beginning of this current increase may correspond, in analogy to the passive metal, the critical pitting potential $\left(E_{\text {pit }}\right)$. This potential moves towards more cathodic potentials when the rotation speed decreases.

As for the current density, except for the blank specimen at stationary electrode, it is essentially independent of the rotation speed, values ca. 2 to $3 \mu \mathrm{A} \mathrm{cm}^{-2}$. The longer the pretreatment period is, the lower the current plateau is.

In the case of pre-treated steel (Fig. $1 \mathrm{~b}$ and 1c), at the low anodic potential domain, the current density is lower compared with untreated specimens, suggesting that the treatment with PPA acts on the anodic active sites.

Fig. 2 presents the variation of the corrosion potential $\left(E_{\text {corr }}\right)$, the pitting potential $\left(E_{\text {pit }}\right)$ and the width of the passive range $\left(\Delta E=E_{\text {pit }}-E_{\text {corr }}\right)$ with respect to the pre-treatment duration in 0.1 M PPA for different rotation speeds.

\section{$<$ Fig. 2>}

It appears that $E_{\text {corr }}$ shifts towards more anodic direction when the rotation speed increases for untreated electrode. In contrast, for the electrode treated during 72 hours, $E_{\text {corr }}$ is the most negative for the rotation speed of $1000 \mathrm{rpm}$. Except this case, the longer is the pre-treatment period, the more positive $E_{\text {corr }}$ is whatever the electrode rotation speed. 
As for $E_{\text {pit, }}$ the longer is the pre-treatment duration, the more positive this potential is, indicating the improvement of the carbon steel against the pitting corrosion. Besides, whatever the pre-treatment duration ( 24 or 72 hours), the increase of the electrode rotation speed moves the pitting potential $\left(E_{\mathrm{pit}}\right)$ of steel towards more cathodic values. The increase of the rotation speed may destabilize the passive film by mechanical constraint, shearing effect, exerted on the electrode surface.

Fig. 2c presents the width of the passive range $(\Delta E)$ calculated from the difference between $E_{\text {pit }}$ and $E_{\text {corr }}\left(\Delta E=E_{\text {pit }}-E_{\text {corr }}\right)$. We remarked that $\Delta E$ decreases when the electrode rotation speed increases. The largest passive range $(\sim 1 \mathrm{~V})$ was observed for the electrode pre-treated during 72 hours for stationary electrode. The narrowest passive domain was observed, on the contrary, for the fastest rotating electrode with untreated carbon steel electrode.

The cathodic polarisation curves obtained for various rotation speeds for carbon steel without and with treatment during 24 or 72 hours in $0.1 \mathrm{M}$ PPA solution are presented in Fig. 3. For blank specimens (untreated carbon steel), the curve exhibits a large diffusion plateau between ca -0.8 and $-1.2 \mathrm{~V}$. The height of this plateau is dependent on the electrode rotation speed. The diffusion plateau was assigned to the reduction of dissolved oxygen involving the transfer of $4 \mathrm{e}^{-}$occurring on an almost uniformly active surface.

The increase of the electrode rotation speed may increase the corrosion rate by two effects:

Due to a faster diffusion of the dissolved oxygen (electrochemical corrosion).

Due to the shearing by the fluid displacement (erosion).

For pre-treated carbon steel (Fig. $3 b$ and 3c), the current plateau observed no longer depends upon the rotation speed. Besides, the current plateau appears at less cathodic potentials than the case of the untreated electrode. This plateau can be related to the diffusion process through the surface film formed by iron oxide and PPA or the adsorption of PPA and does not seem to be limited by the mass transport. 
By the comparison of Fig. $3 \mathrm{a}$ and $3 \mathrm{~b}$ or $3 \mathrm{c}$ we observe a shift of $E_{\text {corr }}$ towards more anodic potentials. That is, the steady-state cathodic current density for the potential domain preceding the current plateau decreases for the pre-treated specimens.

$<$ Fig. 3 $>$

We have applied the Stern - Geary relationship, to evaluate the current density $j$ at the opencircuit potential [40].

$$
j=j_{\text {corr }} \cdot\left\{\exp \left[b_{\mathrm{a}} \cdot\left(E-E_{\text {corr }}\right)\right]-\exp \left[b_{\mathrm{c}}\left(E-E_{\text {corr }}\right)\right]\right\}
$$

where $b_{\mathrm{a}}$ and $b_{\mathrm{c}}$ are the anodic and cathodic Tafel constant $\left(\mathrm{V}^{-1}\right)$, respectively.

The corrosion current density $j_{\text {corr }}$ is then evaluated by a nonlinear regression calculation. The calculation was carried out between about $20 \mathrm{mV}$ to anodic and $50 \mathrm{mV}$ to cathodic from the corrosion potential [41]. Too wide potential range may induce a systematic error, because the system will no longer follow the Tafel law. The results of calculation are presented in Fig. 3d as an example for blank electrode at stationary conditions. It can be seen that the calculated (curve) and experimental data (open circles) overlap very well. The correlation coefficient $R^{2}$ was equal to 0.99993 .

The protective efficiency $(P E)$ in percent was evaluated from the following equation:

$$
P E(\%)=100 \times \frac{j_{\text {corr }}^{0}-j_{\text {corr }}}{j_{\text {corr }}^{0}}
$$

where $j_{\text {corr }}^{0}$ and $j_{\text {corr }}$ denote the corrosion current densities for untreated and pre-treated specimens, respectively. The highest protective efficiency was obtained with the pre-treated electrode during 72 hours in $0.1 \mathrm{M}$ PPA solution for stationary electrode ( $0 \mathrm{rpm})$; it reaches $97 \%$.

We calculated also the Stern-Geary constant $(B)$ by means of the following relationship: When $E=E_{\text {corr: }}$ : 


$$
\frac{\mathrm{d} j}{\mathrm{~d} E}=\frac{1}{R_{\mathrm{p}}}=j_{\text {corr }} \cdot\left(b_{\mathrm{a}}-b_{\mathrm{c}}\right) \text {, then } j_{\text {corr }}=\frac{B}{R_{\mathrm{p}}} \text {, with } B=\frac{1}{b_{a}-b_{c}}
$$

Table 1 summarizes the results of fitting calculations for other experimental conditions. In all cases, the cathodic Tafel constant $b_{\mathrm{c}}$ remains essentially constant whereas the anodic Tafel constant $b_{\mathrm{a}}$ becomes smaller for pre-treated carbon steel ( 24 or 72 hours). This phenomenon can be explained by desorption of the inhibitor [42].

The mean value of constant $\bar{B}$, for the untreated carbon steel (blank), was $29.6 \pm 0.6 \mathrm{mV}$. According to Andrade and al. [43], this value is characteristic of corrosion at active state. $\bar{B}$ value of pre-treated carbon steel was $48.7 \pm 0.7 \mathrm{mV}$; for both duration of pre-treatment (24 or 72 hours) corresponding to the corrosion at passive steel rebar, as attested by a small $b_{\mathrm{a}}$ value [43]. This result is in agreement with that reported by Andrade et al. [44] and indicates the reliability of our results.

$<$ Table 1>

\subsection{ELECTROCHEMICAL IMPEDANCE SPECTROSCOPY}

For the electrochemical impedance spectroscopy (EIS), only the results concerning stationary electrode without or with pre-treated during 72 hours in $0.1 \mathrm{M}$ PPA solution will be shown.

\subsubsection{Protective effect of pre-treatment}

The Fig. 4 shows the impedance spectra in Bode plots of carbon steel without treatment and treated during $72 \mathrm{~h}$ in $0.1 \mathrm{M}$ PPA, obtained after 2 hours of potential stabilization period in the corrosion test solution,. A clear difference is observed between these two diagrams.

For untreated carbon steel, $\log (|Z|)-\log (f)$ curve shows the slope close to -0.5 for the frequency below $10 \mathrm{~Hz}$, indicating the contribution of the diffusion impedance $Z_{\text {dif. }}$. For higher frequencies, in this figure, it seems a contribution of one parallel connection of resistance $R$ and capacitance $C$. however, a parameter regression calculation showed two ladder $R / / C$ are 
necessary to avoid a systematic error. As a whole, the equivalent circuit presented in Fig. 5a was used to reproduce the experimental results.

In this figure, $R_{\mathrm{e}}$ represents the solution resistance. $R_{\mathrm{t}}$ and $C_{\mathrm{dl}}$ stand for the charge transfer resistance and the double capacitance. $R_{\mathrm{F}}$ and $C_{\mathrm{F}}$ are associated to the redox process between $\mathrm{Fe}(\mathrm{II}) \leftrightarrow \mathrm{Fe}(\mathrm{III})$ in the passive layer. $\alpha_{\mathrm{dl}}$ and $\alpha_{\mathrm{F}}$ account for the Cole-Cole dispersion of time constants [45] (Fig. 5a). The use of this type of electric circuit is common in corrosion studies of iron in alkaline media [45].

The impedance spectrum obtained with the pre-treated electrode is formed by one capacitive loop. The corrosion rate is decreased markedly, and as attested by Fig. 3b, the diffusion process no longer intervenes in the reaction kinetics. This is the reason that $Z_{\text {dif }}$ does not appear in the impedance spectrum. Besides, the pre-treatment makes the surface film much stable, and the redox process mentioned above is slowed down substantially, making the disappearance of $R_{\mathrm{F}}$ and $C_{\mathrm{F}}$ couple. Consequently, the diagram is adjusted with a simple equivalent electric circuit illustrated in Fig. 5b.

The results of regression calculations with a simplex method for these two systems were overlaid on Fig. 4. The comparison of experimental and calculated spectra corroborates the adequacy of the equivalent circuit adopted.

$<$ Fig. $4>$

$<$ Fig. 5 $>$

Table 2 shows the values obtained for the circuit elements.

With the pre-treated carbon steel, the value of $C_{\mathrm{dl}}$ is markedly smaller corresponding to the presence of adsorbed inhibitor or the complex film formation. The charge transfer resistance $R_{\mathrm{t}}$ value increases dramatically for the pre-treated carbon steel, which indicates an efficient protective effect of pre-treatment on carbon steel corrosion in the solution simulating chloride 
containing concrete medium. With Stern-Geary equation with $R_{\mathrm{t}}$ instead of $R_{\mathrm{p}}$, the corrosion current density $j_{\text {corr }}$ (Eq. 5), then the protective efficiency PE\% (Eq. 3) were calculated [46].

$$
j_{\text {corr }}=\frac{B}{R_{\mathrm{t}}}
$$

The $B$ value was that determined by the polarization curve and given in Table 1 . The protective effectiveness is higher than $99 \%$. Taking into account of a marked extrapolation to determine $R_{\mathrm{t}}$ for pre-treated specimen, this result is in good agreement with that obtained from polarisation studies.

$<$ Table 2>

\subsubsection{Effect of the immersion time}

Fig. 6 shows the time evolution of impedance spectra in the corrosion test solution for the stationary electrode without and with pre-treatment during $72 \mathrm{~h}$ in $0.1 \mathrm{M}$ PPA. In the case of untreated carbon steel (Fig. 6a), the value of whole impedance modulus decreases considerably with time. Besides, as can be seen from the slope of $\log (|Z|)-\log (f)$ curves close to -0.5 indicating the diffusion impedance below $1 \mathrm{~Hz}$. This behaviour is characteristic of highly active corrosion with appearance and propagation of localized corrosion.

For the pre-treated carbon steel (Fig. 6b), it appears that the phase shift remains high and all diagrams have similar shapes in Nyquit plot, not illustrated here. The impedance behaviour corresponds thus well to that of the passive electrode. They are formed all of them by only one capacitive branch as presented above (Fig. 4). The imaginary component increases with immersion time, that is, the interface capacitance decreases with time. We can conclude that in spite of chloride ions, the passive film increases its thickness because of highly alkaline medium and the film formed on steel surface during the pre-treatment reveals highly satisfactory inhibiting properties. Fig. 1c shows also clearly that $E_{\text {corr }}$ is much cathodic than $E_{\text {pit }}$ The efficiency of this protective layer is therefore not altered with time. 
$<$ Fig. 6 $>$

\subsection{GRAVIMETRIC MEASUREMENTS}

In this part, the mass and the potential change with respect to time of carbon steel without treatment or the pre-treated specimen (during $72 \mathrm{~h}$ in a $0.1 \mathrm{M}$ PPA) in the corrosion test solution (Figs. 7 and 8) will be presented.

In absence of treatment (Fig. 7), the mass decreases slightly $\left(3 \mu \mathrm{g} \mathrm{cm}{ }^{-2}\right)$ for about 6 hours, then decreases continuously with time. As for the potential, it increases during one day, thus can be explained by the effect of highly alkaline medium to the passivation of metal. After two days of immersion, the potential decreases steeply and stabilizes at about -0.55 Vsce after three days immersion. This potential change is a signature of the beginning of a local attack of metal because the protective layer was damaged by chloride ions. This analysis is confirmed by a steep decrease of the electrode mass by EQCM data.

On Fig. 8, the mass and potential changes during the pre-treatment period, 72 hours, are also presented. At 72 hours of immersion, the electrode was transferred into the corrosion test solution. During the pre-treatment (Fig. 8), it appears that the open-circuit potential increases continuously during the whole pre-treatment period. Beyond this period, the potential stabilizes in aggressive solution at about the $10^{\text {th }}$ day. The mass of the products formed at the interface increases (at the moment of immersing sample after pre-treatment in testing solution): up to $70-100 \mu \mathrm{g} / \mathrm{cm}^{2}$. We think that this is related with the deposition of Ca-PPA complex. This mass increases with time revealing an improvement of the film formed on the steel surface. The observed fluctuations are owed to the temperature fluctuation corresponding to periods of day and night. Indeed, we did not use a thermostatically controlled cell.

$<$ Fig. $7>$

$<$ Fig. $8>$ 
Figs. 9 and 10 present the surface morphology and the results of EDS analysis of the sample without and with pre-treatment, respectively, at the end of the test. In the case of blank sample, a local attack of the steel surface as pitting by chloride ions can be observed clearly. On the contrary, with pre-treatment, almost no corrosion is revealed; some precipitates (white heap in SEM picture) are appeared probably because of insufficient surface rinsing and this precipitate will be not highly soluble such as $\mathrm{CaCO}_{3}$. The EDS analysis showed the presence of the phosphorus, likely due to the formation of Fe - PPA complex.

<Fig. 9>

$<$ Fig. 10>

\section{CONCLUSIONS}

To evaluate the protective effectiveness of pre-treatment by immersion of carbon steel reinforcement in 0.1M Phenyl Phosphonic Acid (PPA), various experimental methods were applied. The experiments were carried out in an aqueous electrolyte medium simulating interstitial concrete pore solution contaminated by seawater:

1. Polarisation curves showed that the pre-treatment of carbon steel induces a decrease of the corrosion current density, and the corrosion potential shift towards more anodic direction. Therefore, the passive state of low carbon steel is improved substantially by the pretreatment.

2. Impedance measurements provided information related to the formation and evolution of the protective layer. The pre-treatment of carbon steel during $72 \mathrm{~h}$ in $0.1 \mathrm{M}$ PPA solution allows the formation of an efficient protective layer on the surface against the corrosion of carbon steel in alkaline chloride media. The protective effectiveness is estimated higher than $99 \%$. 
3. Gravimetric measurements obtained by electrochemical quartz crystal microbalance (EQCM) show that the mass of the products formed at the interface increases with time revealing a thickening of the film formed on the steel surface.

4. EDS analysis indicated the presence of the phosphorus on the steel surface, suggesting the presence of Fe - PPA complex.

\section{ACKNOWLEDGEMENTS}

The authors acknowledge the financial support received from the French embassy in Tunisia that allowed among others the trainees of NE at LISE, and to develop the experiments.

\section{REFERENCES}

1. Elsener B, Büchler M, Stalder F, Böhni H. Migrating Corrosion Inhibitor Blend for Reinforced Concrete: Part 2-Inhibitor as Repair Strategy. Corros 2000;56(7):727-732.

2. Monticelli C, Frignani A, Trabanelli G. A study on corrosion inhibitors for concrete application. Cem Conc Res 2000;30(4):635-642.

3. Dhouibi L, Triki E, Raharinaivo A. The application of electrochemical impedance spectroscopy to determine the long-term effectiveness of corrosion inhibitors for steel in concrete. Cem Concr Compos 2002;24(1):35-43.

4. Elsener B. Corrosion inhibitors for reinforced concrete. In: Banas J, Filipek R, Zurek Z, editors. Proceeding 7th Polish corrosion conference. J Ochrona Przed Korozja; 2002. p. $25-33$.

5. Jamil HE, Montemor MF, Boulif R, Shriri A, Ferreira MGS. Electrochemical behaviour of amino alcohol-based inhibitors used to control corrosion of reinforcing steel. Electrochim Acta 2004;49: 2753-2760.

6. Batis G, Pantazopoulou P, Routoulas A. Corrosion protection investigation of reinforcement by inorganic coating in the presence of alkanolamine-based inhibitor. Cem Concr Compos 2003;25(3):371-377.

7. Berke NS, Hicks MC. Predicting long-term durability of steel reinforced concrete with calcium nitrite corrosion inhibitor. Cem Conc Compos 2004;26(3):191-198.

8. Monticelli C, Frignani A, Brunoro G, Trabanelli G, Zucchi F, Tassinari M. Corrosion inhibition of steel in alkaline chloride solutions. Corros Sci 1993;35:1483-1489. 
9. Tommaselli MAG, Mariano NA, Kuri SE. Effectiveness of corrosion inhibitors in saturated calcium hydroxide solutions acidified by acid rain components. Construc Build Mater 2009:328-333.

10. Monticelli C, Frignani A, Balbo A, Zucchi F. Influence of two specific inhibitors on steel corrosion in a synthetic solution simulating a carbonated concrete with chlorides. Mater Corros 2011;62(2):178-186.

11. Zafeiropoulou T, Rakanta E, Batis G. Performance evaluation of organic coatings against corrosion in reinforced cement mortars. Progress in Organic Coatings 2011;72:175-180.

12. Mechmeche L, Dhouibi L, Ben Ouezdou M, Triki E, Zucchi F. Investigation of the early effectiveness of an amino-alcohol based corrosion inhibitor using simulated pore solutions and mortar specimens. Cem Conc Compos 2008;30:167-173.

13. Goñi S, Andrade C. Synthetic concrete pore solution chemistry and rebar corrosion rate in the presence of chlorides. Cem Conc Res 1990;20(4):525-539.

14. Xu LJ, Jiang L, Xing F. Influence of $N, N^{\prime}$-dimethylaminoethanol as an inhibitor on the chloride threshold level for corrosion of steel reinforcement. Mater Corros 2010;61(9):802-809.

15. Dhouibi L, Triki E, Raharinaivo A, Trabanelli G, Zucchi F. Electrochemical methods for evaluating inhibitors of steel corrosion in concrete. Br Corros J 2000;35(2):145-149.

16. Etteyeb N, Dhouibi L, Takenouti H, Alonso MC, Triki E. Corrosion inhibition of carbon steel in alkaline chloride media by $\mathrm{Na}_{3} \mathrm{PO}_{4}$. Electrochimi Acta 2007;52:7506-7512.

17. Etteyeb Naceur, Dhouibi Leila, Sanchez Mercedes, Alonso Cruz, Andrade Carmen, Triki Ezzeddine. Electrochemical study of corrosion inhibition of steel reinforcement in alkaline solutions containing phosphates based components. J Mater Sci 2007;42:4721-4730.

18. Andrade C, Alonso C, Acha M, Malric B. Preliminary testing of $\mathrm{Na}_{2} \mathrm{PO}_{3} \mathrm{~F}$ as a curative corrosion inhibitor for steel reinforcements in concrete. Cem Concr Res 1992;22:869-881.

19. Alonso C, Andrade C, Argiz C, Malric B. $\mathrm{Na}_{2} \mathrm{PO}_{3} \mathrm{~F}$ as inhibitor of corroding reinforcement in carbonated concrete. Cem Concr Res 1996;26(3):405-415.

20. Ngala VT, Page CL, Page MM. corrosion inhibitor systems for remedial treatment of reinforced concrete. Part 2: Sodium monofluorophosphate. Corros Sci 2003;45:15231537.

21. Nakayama N. Inhibitory effects of nitrilotris(methylenephosphonic acid) on cathodic reactions of steels in saturated $\mathrm{Ca}(\mathrm{OH})_{2}$ solutions. Corros Sci 2000;42:1897-1920. 
22. Garcia C, Gourbin G, Ropital F, Fiaud C. Study of the scale inhibition by HEDP in a channel flow cell using a quartz crystal microbalance. Electrochim Acta 2001;46(7):973985.

23. Starostina M, Smorodin A, Gal-Or L. Inhibition by phosphates of mild steel and cast iron in cooling water. Mater Perform 1999;32(3):52-58.

24. Cushner MC, Melhior WC, Przybylinski JL. Effect of iron(II) on the performance of calcium carbonate inhibitors $=$ Influence du fer(II) sur les performances des inhibiteurs de carbonate de calcium. Mater Perform 1990;29(1):49-52.

25. Sekine I, Hirakawa Y. Effect of 1-Hydroxyethylidene-1, 1-Diphosphonic Acid on the Corrosion of SS 41 Steel in 0.3\% Sodium Chloride Solution. Corros 1986;42(5):272-277.

26. Fang JL, Li Y, Ye XR, Wang ZW, Liu Q. Passive Films and Corrosion Protection Due to Phosphonic Acid Inhibitors. Corros 1993;49(4):266-271.

27. Rajendran S, Apparao BV, Palaniswamy N. Corrosion inhibition by phenyl phosphonate and Zn. Anti-Corros Methods Mater 1998;45(3) :158-161.

28. Gunasekaran G, Palaniswamy N, Apparao BV, Muralidharan VS. Synergistic inhibition in low chloride media. Electrochim Acta 1997;42(9):1427-1434.

29. To XH, Pebere N, Peleprat N, Boutevin B, Hervaud Y. A corrosion-protective film formed on a carbon steel by an organic phosphonate. Corros Sci 1997;39:1925-1934.

30. Etteyeb N, Sanchez M, Dhouibi L, Alonso C, Andrade C, Triki E. Corrosion protection of steel reinforcement by a pretreatment in phosphate solutions: assessment of passivity by electrochemical techniques. Corros Eng Sci Tech 2006;41(4):336-341.

31. Abd El Haleem SM, Abd El Wanees S, Abd El Aal EE, Diab A. Environmental factors affecting the corrosion behavior of reinforcing steel II. Role of some anions in the initiation and inhibition of pitting corrosion of steel in $\mathrm{Ca}(\mathrm{OH})_{2}$ solutions. Corros Sci 2010;52(2):292-302.

32. Haran BS, Popov BN, Petrou MF, White RE. Studies on Galvanized Carbon Steel in $\mathrm{Ca}(\mathrm{OH})_{2}$ Solutions. ACI Struct J 2000;97(4):425-431.

33. Andrade C. Corrosion of steel reinforcement, Chapter 6, Environmental Deterioration of Materials, Editor A. Moncmanová, Slovakia, 2007;p.185.

34. Andrade C, Page CL. Pore solution chemistry and corrosion in hydrated cement systems containing chloride salts: a study of cation specific effects. B Corros j 1986;21(1):49-54.

35. Mammoliti LT, Brown LC, Hansson C, Hope BB. The influence of surface finish of reinforcing steel and ph of the test solution on the chloride threshold concentration for corrosion initiation in synthetic pore solutions. Cem Conc Res 1996;26(4):545-550. 
36. Alonso C, Castellote M, Andrade C. Chloride threshold dependence of pitting potential of reinforcements. Electrochim Acta 2002;47:3469-3481.

37. Bernard MC, Dauvergne E, Evesque M, Keddam M, Takenouti H. Reduction of silver tarnishing and protection against subsequent corrosion. Corr Sci 2005;47:663-679.

38. Sauerbrey G. Verwendung von Schwingquarzen zur Wägung dünner Schichten und zur Mikrowägung. Z Phys 1955;155:206-222.

39. Gabrielli C, Keddam M, Torresi R. Calibration of the Electrochemical Quartz Crystal Microbalance. J Electrochem Soc 1991;138(9):2657-2660.

40. Stern M, Geary AL. Electrochemical Polarization I: A Theoretical Analysis of the Shape of Polarization Curves. J Electrochem Soc 1957;104(1):56-63.

41. Muresan L, Varvara S, Stupnisek-Lisac E, Otmacic H, Marusic K, Horvat-Kurbegovic S, Robbiola L, Rahmouni K, Takenouti H. Protection of bronze covered with patina by innoxious organic substances. Electrochim Acta 2007;52:7770-7779.

42. Dermaj A, Hajjaji N, Joiret S, Rahmouni K, Srhiri A, Takenouti H, Vivier V. Electrochemical and spectroscopic evidences of corrosion inhibition of bronze by a triazole derivative. Electrochim Acta 2007;52:4654-4662.

43. Andrade C, Castelo V, Alonso C, Gonzalez JA. Corrosion Effect of Stray Currents and the Techniques for Evaluating Corrosion of Rebars in Concrete, ASTM STP 906, Chaker V. Ed., American Society for Testing and Materials, Philadelphia, 1986;p.43.

44. Andrade C, Alonso MC, Gonzalez JA. Corrosion rates of steel in concrete, ASTM STP 1065, Berke NS, Chaker V, Whiting D. Eds., American society for testing and Materials, Philadelphia, 1990;p.29.

45. Diaz B, Joiret S, Keddam M, Novoa XR, Perez MC, Takenouti H. Passivity of iron in red mud's water solutions. Elecrochim Acta 2004;49:3039-3048.

46. I Epelboin, C. Gabrielli, M. Keddam, H. Takenouti, A-C impedance measurements applied to corrosion studies and corrosion rate determination, in "Electrochemical Corrosion Testing”, F. Mansfeld and U. Bertocci editors, STP 727,150-192. American Society for Testing and Materials, Philadelphia, Pa (1981) 
Figure captions:

Fig. 1: Anodic polarisation curves of the (a) untreated; (b) 24-hour and (c) 72-hour treated carbon steel in $0.1 \mathrm{M}$ PPA and then transferred to the corrosion test solution.

Fig. 2: Variation of the corrosion potential $\left(E_{\text {corr }}\right)$, the pitting potential $\left(E_{\text {pit }}\right)$ and $\left(E_{\text {pit }}-E_{\text {corr }}\right)$ range with respect to the pre-treatment duration in 0.1 M PPA for different rotation speeds

Fig. 3: Cathodic polarisation curves of the (a) untreated; (b) 24-hours and (c) 72-hours treated carbon steel (in $0.1 \mathrm{M}$ PPA) and then immersed in the corrosion test solution (d) the experimental and calculated $\mathrm{j}$-E curves for untreated and stationary electrode.

Fig. 4: EIS spectra of untreated and 72 hours pre-treated carbon steel then immersed during 2 hours in the corrosion test solution.

Fig. 5: Equivalent electrical circuit reproducing the results presented on Fig. 4 (a) for the untreated carbon steel (b) for pre-treated carbon steel.

Fig. 6: Time change of impedance spectra of (a) untreated carbon steel (b) $72 \mathrm{~h}$ pre-treated steel in $0.1 \mathrm{M}$ PPA; immersed in the corrosion test solution. $\Omega=0 \mathrm{rpm}$.

Fig. 7: Variation versus time of mass and potential of untreated carbon steel immersed in the corrosion test solution.

Fig. 8: Variation versus time of mass and potential of carbon steel treated during $72 \mathrm{~h}$ in a 0.1 M PPA solution, then immersed in the corrosion test solution.

Fig. 9: SEM picture and EDS analysis of the untreated sample at the end of electrochemical quartz crystal microbalance test.

Fig. 10: SEM picture and EDS analysis of the $72 \mathrm{~h}$ pre-treated sample in the end of electrochemical quartz crystal microbalance test. 

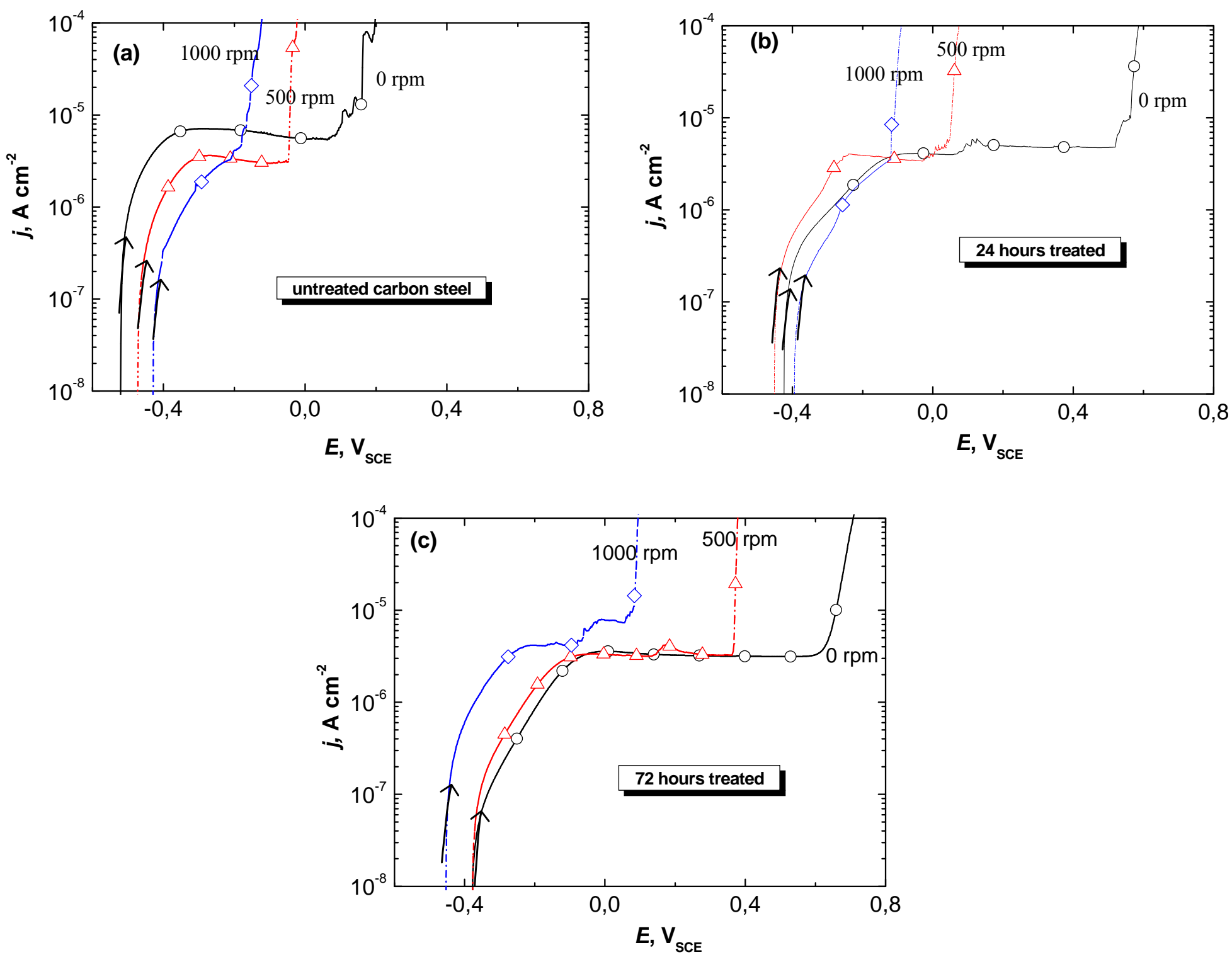

Fig. 1: 

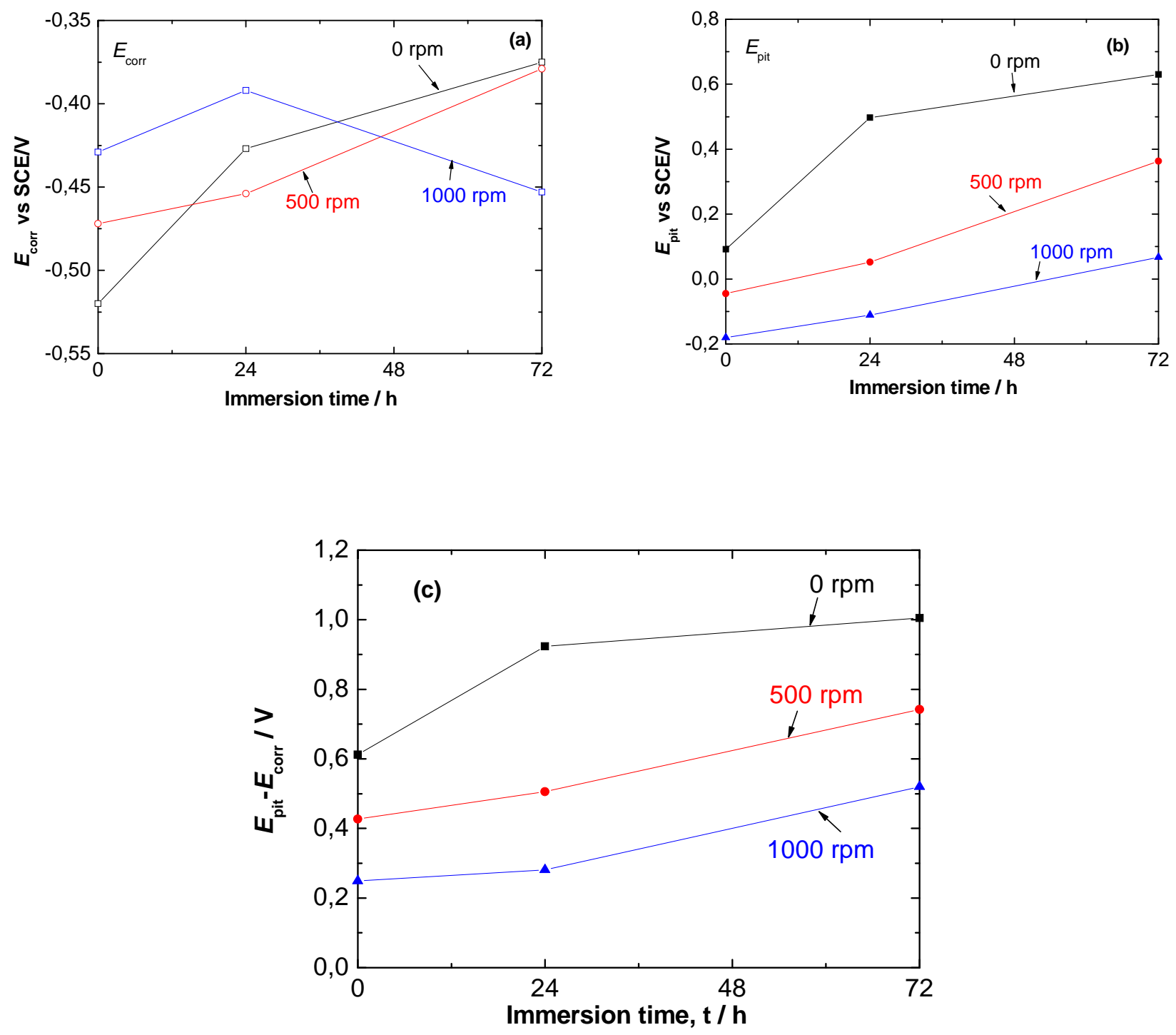

Fig. 2: 

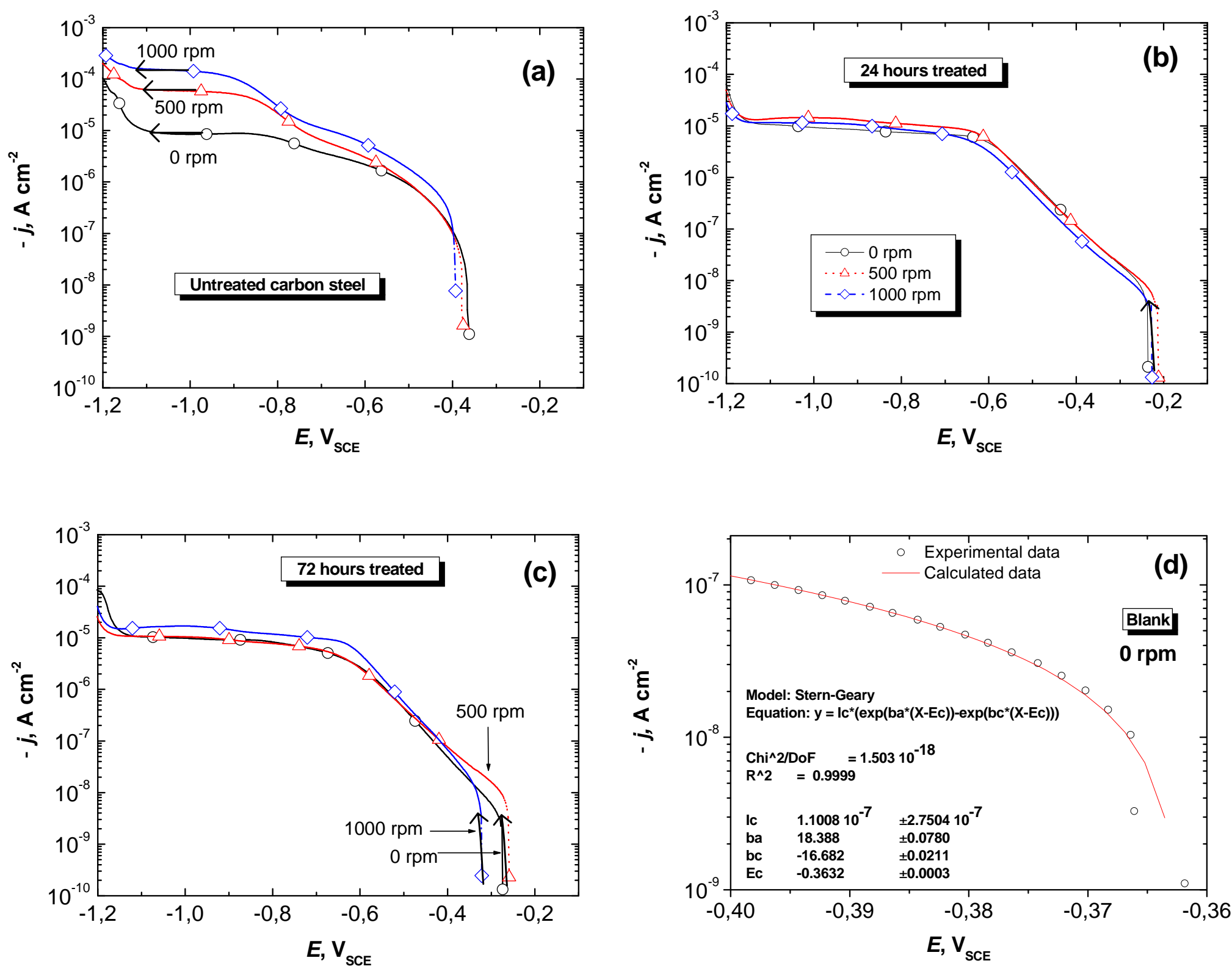

Fig. 3: 


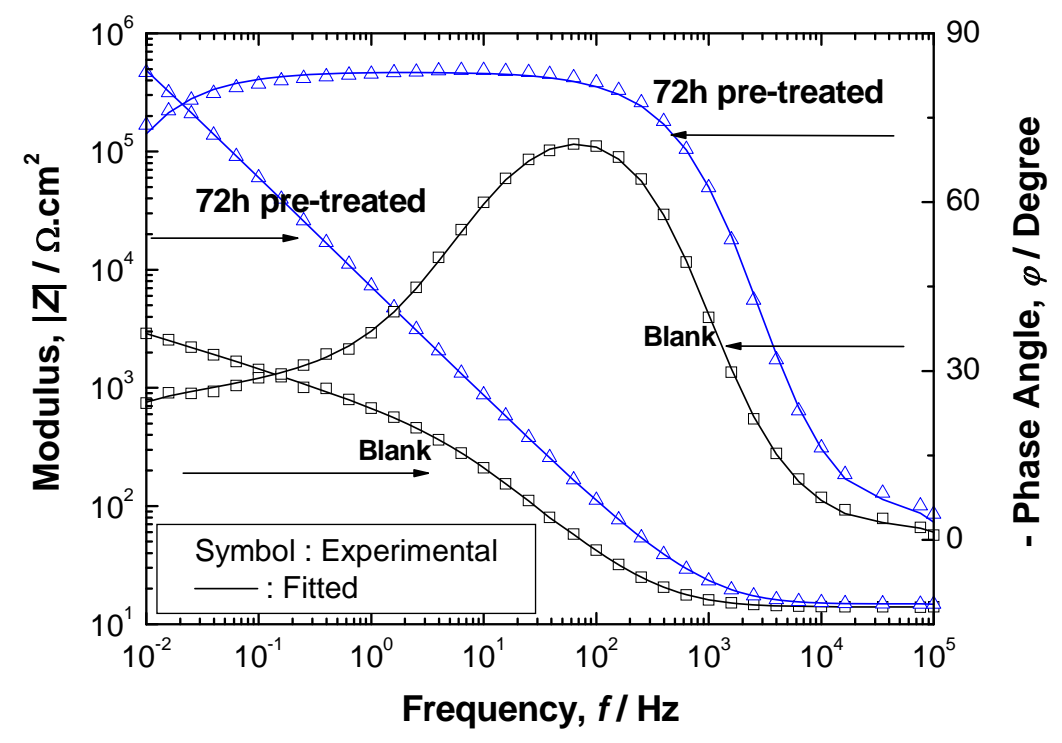

Fig. 4:

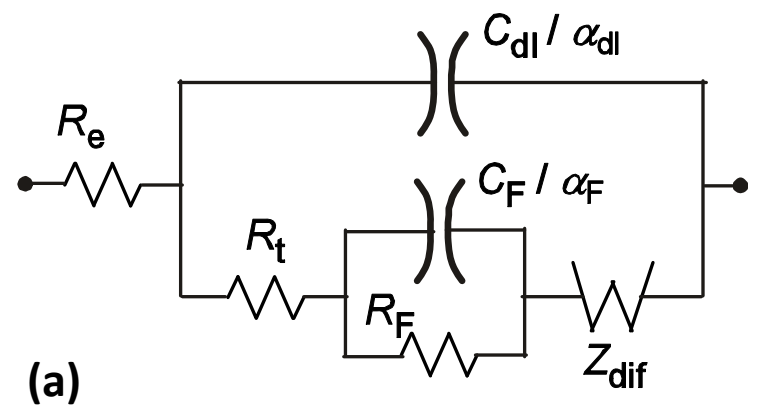

(b)

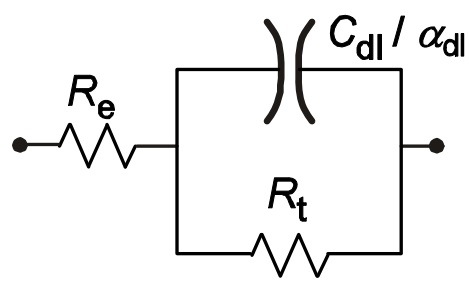

Fig. 5: 

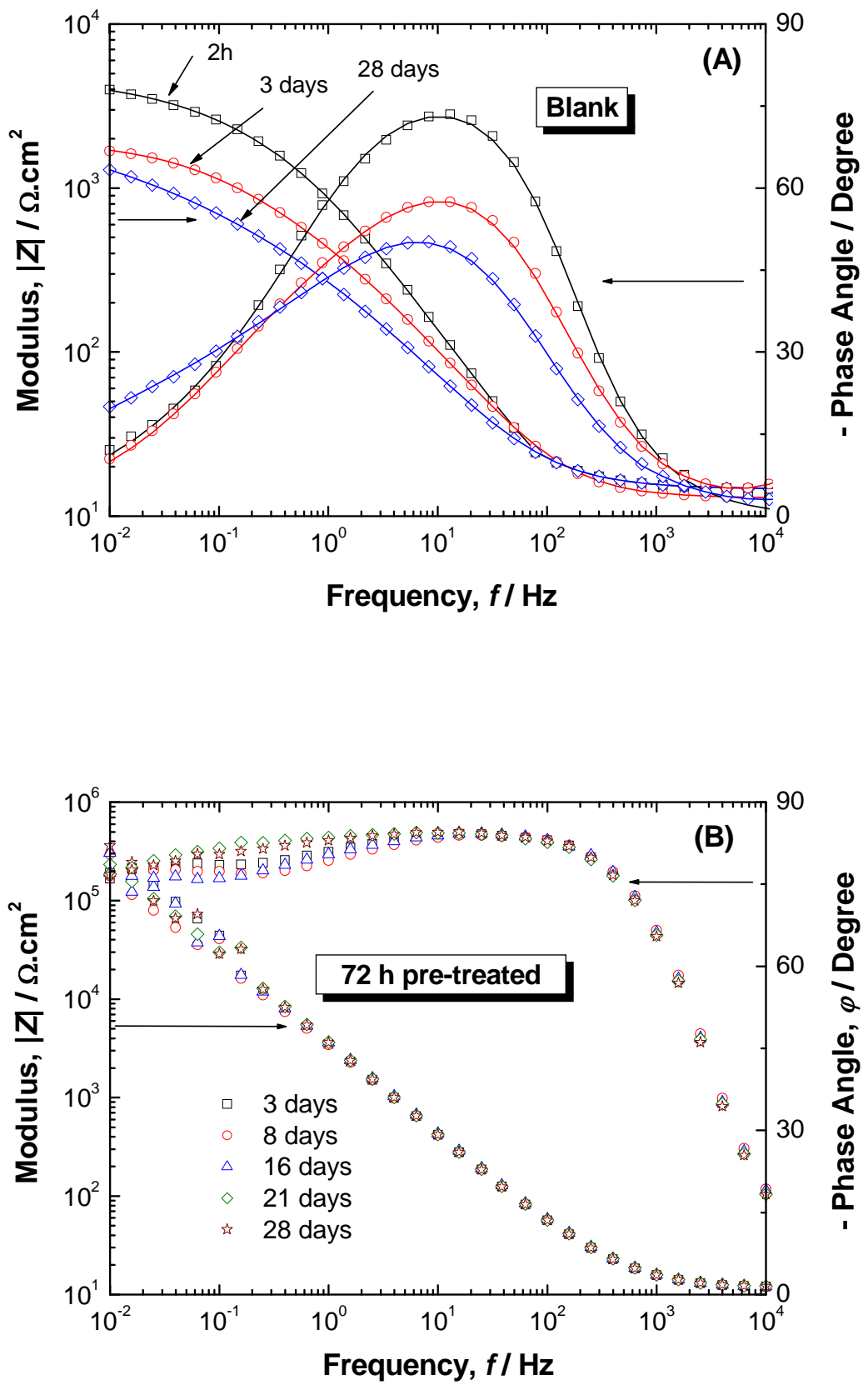

Fig. 6: 


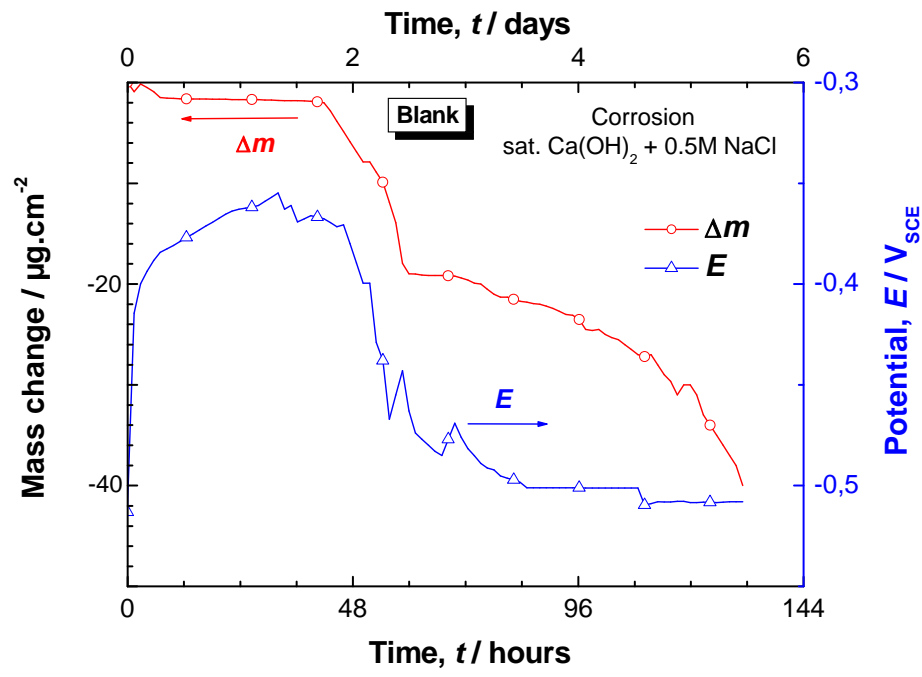

Fig. 7:

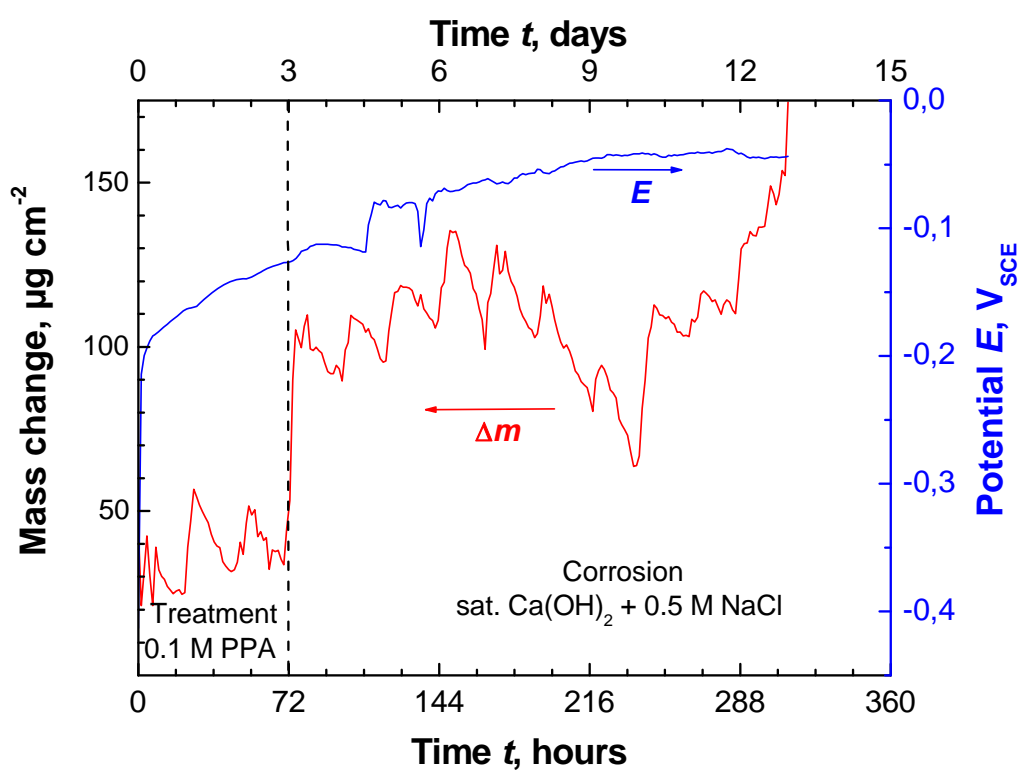

Fig. 8: 

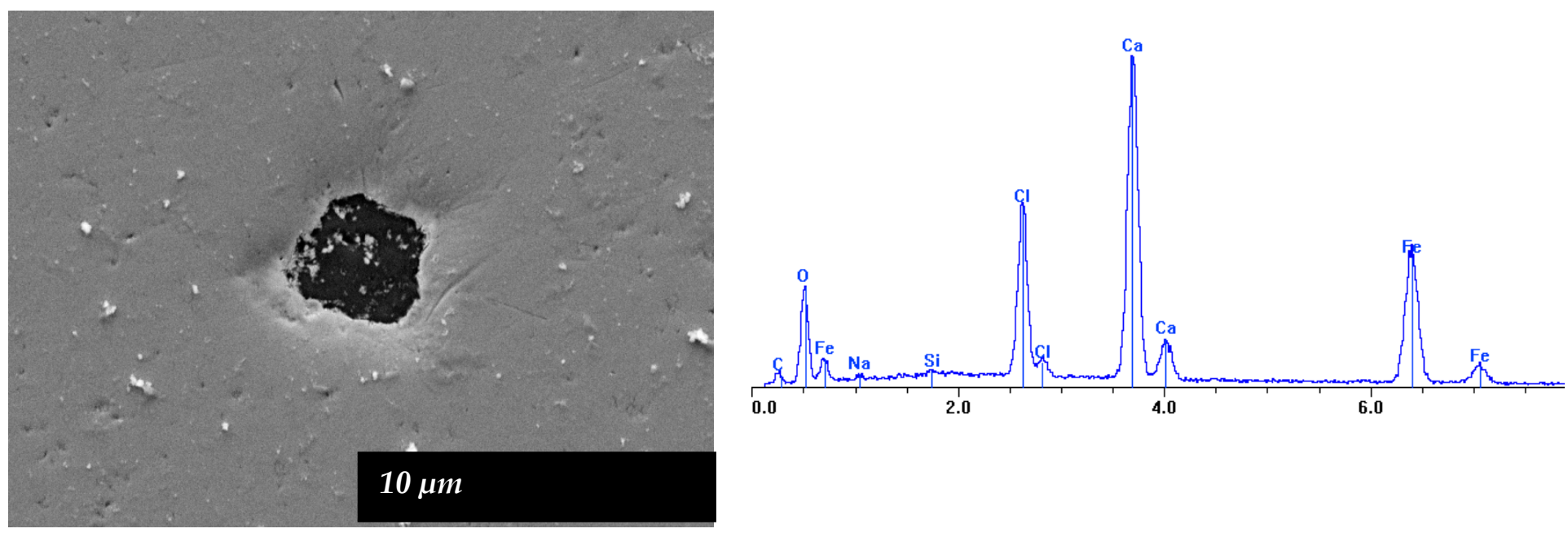

Fig. 9:
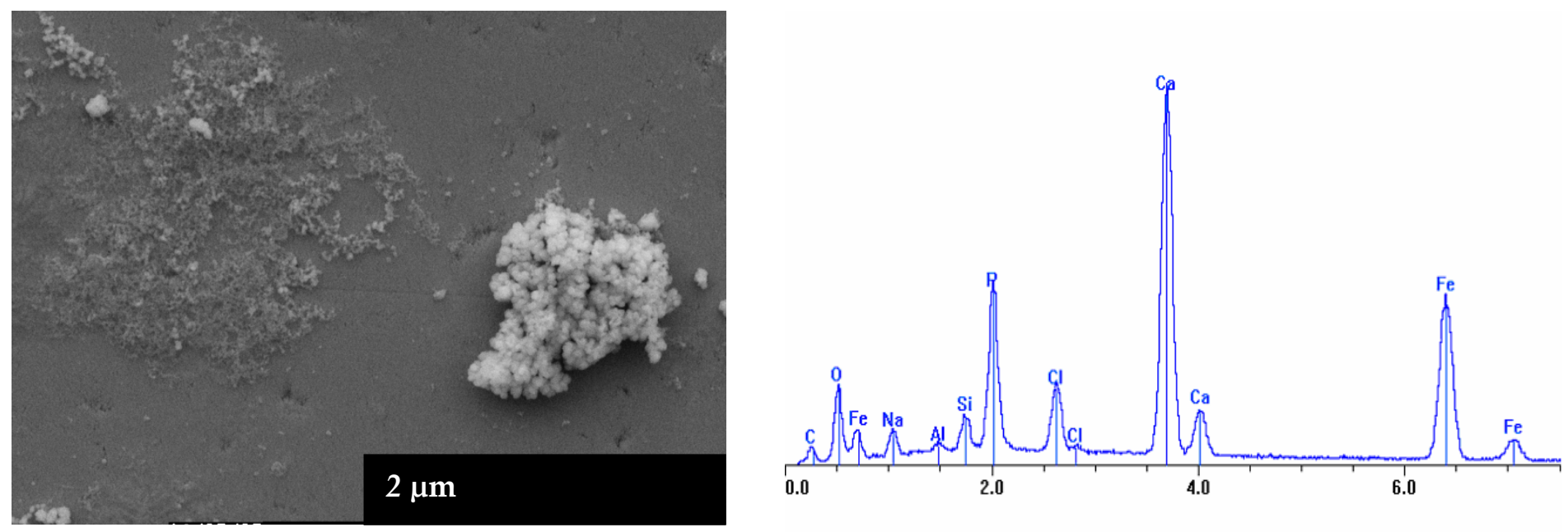

Fig. 10: 
Table:

Table 1: Results of regression calculation for the evaluation of corrosion parameters from cathodic potential scan data.

\begin{tabular}{|c|c|c|c|c|c|c|c|}
\hline & $\Omega / \mathrm{rpm}$ & $E_{\text {corr }} / \mathrm{V} / \mathrm{ECS}$ & $j_{\text {corr }} / \mathrm{nA} / \mathrm{cm}^{2}$ & $P E(\%)$ & $b a / V^{1}$ & $b c / V^{1}$ & $B / m V$ \\
\hline & 0 & -0.36 & 110 & - & 18.4 & -11 & 28.5 \\
\hline \multirow[t]{3}{*}{ Blank } & 500 & -0.37 & 129 & - & 18.9 & $-1:$ & 30.5 \\
\hline & 1000 & -0.39 & 216 & - & 19.7 & $-1:$ & 29.9 \\
\hline & 0 & -0.27 & 6.76 & 93.9 & 4.73 & $-1:$ & 48.4 \\
\hline \multirow[t]{3}{*}{$24 \mathrm{~h}$ pre-treated } & 500 & -0.26 & 15.1 & 88.3 & 5.07 & $-1:$ & 49.2 \\
\hline & 1000 & -0.32 & 19.4 & 91.0 & 5.43 & $-1:$ & 47.9 \\
\hline & 0 & -0.23 & 3.16 & 97.1 & 4.83 & -11 & 47.4 \\
\hline \multirow[t]{2}{*}{$72 \mathrm{~h}$ pre-treated } & 500 & -0.23 & 11.6 & 91.0 & 5.17 & -1 & 49.9 \\
\hline & 1000 & -0.23 & 15.6 & 92.8 & 5.35 & $-1:$ & 48.7 \\
\hline
\end{tabular}

Table 2: Parameters obtained by fitting experimental impedance data presented in Fig. 4

\begin{tabular}{lrrrrrrrr}
\hline & $\begin{array}{c}R_{\mathrm{t}} \\
\left(\mathrm{k} \Omega . \mathrm{cm}^{2}\right)\end{array}$ & $\begin{array}{c}C_{\mathrm{dl}} \\
\left(\mu \mathrm{F} . \mathrm{cm}^{-2}\right)\end{array}$ & $\begin{array}{c}R_{\mathrm{F}} \\
\left(\mathrm{k} \Omega . \mathrm{cm}^{2}\right)\end{array}$ & $\begin{array}{c}C_{\mathrm{F}} \\
\left(\mathrm{mF} . \mathrm{cm}^{-2}\right)\end{array}$ & $\begin{array}{c}R_{\mathrm{d}} \\
\left(\mathrm{k} \Omega . \mathrm{cm}^{2}\right)\end{array}$ & $\begin{array}{c}\tau_{\mathrm{d}} \\
(\mathrm{s})\end{array}$ & $\begin{array}{c}j_{\mathrm{corr}} \\
(\mu \mathrm{Acm})\end{array}$ & $\begin{array}{c}P E \\
(\%)\end{array}$ \\
\hline Untreated & 7.53 & 210 & 11.5 & 35 & 16.5 & 14.80 & 3.78 & - \\
pre-treated & 1700 & 25.1 & - & - & - & - & 0.03 & 99.2 \\
\hline
\end{tabular}

